\title{
New insight into the mechanism of cathodic electrodeposition of zinc oxide thin films onto vitreous carbon.
}

\author{
Ait Ahmed N. ${ }^{(1,3)}$, Eyraud M. ${ }^{(2)}$, Hammache H..$^{(1)}$, Vacandio F. ${ }^{(2)}$, Sam S. ${ }^{(3)}$, Gabouze N..$^{(3)}$, \\ Knauth P. ${ }^{(2)}$, Pelzer K. ${ }^{(2)}$, Djenizian T. ${ }^{(4)}$
}

(1) Université Abderrahmane Mira, Laboratoire de Technologie des matériaux et Génie des Procédés : Equipe d'électrochimie - Corrosion, Bejaia, 06000 Algérie.

(2) Aix-Marseille Université - CNRS, UMR 7246 : Laboratoire Madirel, Equipe : Electrochimie des Matériaux13397 Marseille Cedex 20, France

(3) Unité de Développement de la Technologie du Silicium (UDTS), B.P. 399, Alger-Gare Alger, Algérie.

(4) Aix-Marseille Université - CNRS, UMR 7341 : Laboratoire LP3, Equipe : Chimie des Matériaux-Campus de Luminy- 13288 Marseille cedex 9, France.

\begin{abstract}
In this study, the mechanism of zinc oxide $(\mathrm{ZnO})$ electrodeposition from aqueous zinc nitrate solution at $70^{\circ} \mathrm{C}$ was investigated on vitreous carbon and bulk zinc electrodes using cyclic voltammetry experiments. Mechanisms are presented for the $\mathrm{ZnO}$ formation: the first widely accepted route corresponds to $\mathrm{ZnO}$ precipitation from $\mathrm{Zn}^{2+}$ and $\mathrm{OH}^{-}$produced by $\mathrm{NO}_{3}{ }^{-}$reduction; the second route, which is discussed in this article, is due to $\mathrm{Zn}^{2+}$ reduction into metallic $\mathrm{Zn}$ followed by its oxidation by nitrate ions. For this case, we demonstrate why $\mathrm{Zn}$ formation can not be observed while $\mathrm{Zn}^{2+}$ reduction was detected. Structural and morphological of bulk deposits were investigated using X-ray diffraction and scanning electron microscopy. Welloriented $\mathrm{ZnO}$ nanorods forming thin films were grown on vitreous carbon from $\mathrm{Zn}\left(\mathrm{NO}_{3}\right)_{2}$ solution at low cathodic potential corresponding to that of zinc metal deposition. X-ray diffraction $(\mathrm{XRD})$ measurements showed that the nanorods are crystalline and preferably grown along the (002) direction.
\end{abstract}

Keywords: $\mathrm{ZnO}$ deposition mechanism, cyclic voltametry, nanowires, nitrate solutions

\section{Introduction}

Zinc oxide $(\mathrm{ZnO})$ is one of the most important binary II-VI semiconductor compounds, which has a hexagonal wurtzite structure. It presents typically n-type electrical conductivity and a band gap energy between 3.2 and $3.4 \mathrm{eV}$ at room temperature. $\mathrm{ZnO}$ has a large exciton binding energy 
$(60 \mathrm{meV})$ at room temperature, which is much higher than that of $\mathrm{ZnS}(20 \mathrm{meV})$ and $\mathrm{GaN}(21$ $\mathrm{meV}$ ). This makes $\mathrm{ZnO}$ an ideal material to realize room temperature excitonic devices. Several techniques have been used for the production of $\mathrm{ZnO}$ thin films such as chemical vapor deposition [1, 2], sol-gel [3-5], radio frequency sputtering [6], pulsed laser deposition [7], spraypyrolysis [8] and chemical oxidation of Zn [9].

Electrochemical deposition (ECD) is emerging as an important method to prepare semiconductor thin films such as $\mathrm{ZnO}$; this method presents interesting characteristics for large-area, low-cost, generally low-temperature and soft processing of materials. This technique allows also an easy control of the dimensions of nanostructures by means of appropriate growth parameters $[10,11]$. The one-step electrodeposition of $\mathrm{ZnO}$ films has been extensively reported [10], using oxygen dissolved in an aqueous solution at $70^{\circ} \mathrm{C}$. Izaki and Omi [12] were the first to report $\mathrm{ZnO}$ formation at the cathode by using nitrate ions as oxygen precursor. In these two media, the mechanism of $\mathrm{ZnO}$ formation is induced either by oxygen or nitrate ions reduction at the cathode surface [13 - 20]. The hydroxide ions then produced can react with $\mathrm{Zn}^{2+}$ at the vicinity of the cathode to precipitate zinc hydroxide that is finally transformed into $\mathrm{ZnO}$. In this generally admitted mechanism no attention is paid to the electrochemical reduction of $\mathrm{Zn}^{2+}$ into metallic zinc. More precisely, it is not clear why the direct $\mathrm{Zn}^{2+}$ reduction into $\mathrm{Zn}$ is not observed while the potential used for the reduction is often close to that of the $\mathrm{Zn}^{2+} / \mathrm{Zn}$ redox couple.

More recently, an innovative route to obtain nanocrystalline $\mathrm{ZnO}$, has been proposed by Azaceta et al. in an oxygenated trifluoromethane sulfonyl imide (TFSI) ionic liquid [21, 22]. The mechanism reported here, consists again in chemical reaction between $\mathrm{Zn}^{2+}$ and superoxide ions $\left(\mathrm{O}_{2}{ }^{-}\right)$that are generated from $\mathrm{O}_{2}$ reduction, pointing out the absence of metallic $\mathrm{Zn}$ intermediate. Furthermore, several papers reported the preparation of $\mathrm{ZnO}$ films on conductive oxide or semiconductive electrode substrates, such as indium tin oxide (ITO) [23], fluorine-doped tin oxide (FTO) [24], n-type silicon [10] and gallium nitride [25]. However, to the best of our knowledge there is no report about depositing $\mathrm{ZnO}$ on vitreous carbon from an aqueous solution by an electrochemical method. The selected substrate presents the necessary qualities to have a better insight in the deposition mechanism: it has an amorphous structure with no influence on that of the deposit, especially with metallic deposits, and has a high overpotential for hydrogen evolution that often hides the reduction currents of the other species [26].

Accordingly, the present work has been carried out with the aim to understand the growth mechanism of $\mathrm{ZnO}$ on vitreous carbon using cyclic voltammetry experiments. Some complementary experiments were also performed on a bulk zinc electrode to support the 
proposed mechanism. The influence of various deposition parameters (such as zinc (II) and nitrate concentrations or the applied potential) on $\mathrm{ZnO}$ thin films were also investigated using Xray diffraction (XRD), energy dispersive X-ray spectroscopy (EDX) and scanning electron microscopy (SEM).

\section{Experimental}

The electrodeposition was carried out in a three-electrode cell system that consists of a vitreous carbon or a zinc working electrode, a saturated calomel electrode (SCE) as the reference electrode and a platinum foil as the counter electrode. Electrochemical experiments were carried out using a potentiostat/galvanostat (Solartron 1287). All chemicals were of analytical grade and were used without further purification. All solutions were prepared with deionized water purified with a Millipore Milli-Q purification system (resistivity $\geq 18 \mathrm{M} \Omega . \mathrm{cm}$ ). Before the electrodeposition, the vitreous carbon or zinc electrodes were mechanically polished using emery papers of grades 2400 and 1000 . They were subsequently polished by diamond slurry on a polishing cloth, followed by a thorough distilled water rinsing. The polishing procedure was followed by five minutes of ultrasonication to clean the surface. The deposition solutions consisted in $0.005 \mathrm{M} \mathrm{Zn}\left(\mathrm{NO}_{3}\right)_{2}$ with an initial $\mathrm{pH} \sim 6.5$ and the deposition temperature was $70^{\circ} \mathrm{C}$. All experiments were made after careful de-aeration of the solutions by argon flow.

The crystal structure of the electrodeposited $\mathrm{ZnO}$ nanostructures was characterized by X-ray diffraction (XRD) using a Siemens D5000 diffractometer with $\mathrm{Cu} K \alpha$ radiation $(\lambda=0.15406 \mathrm{~nm})$. The surface morphology and composition of $\mathrm{ZnO}$ were investigated by a scanning electron microscope (SEM) (Hitachi, S-570) equipped with X-ray energy dispersive spectroscopy (EDX). SUPPRIME UV

\section{Results and discussion}

\subsection{Cyclic voltammetry}

The electrochemical formation mechanism of $\mathrm{ZnO}$ is known $[11,18,27,28-30]$ to be initiated by the reduction of nitrate ions that produces hydroxide ions, followed by the precipitation of $\mathrm{Zn}(\mathrm{OH})_{2}$. The conversion of $\mathrm{Zn}(\mathrm{OH})_{2}$ into $\mathrm{ZnO}$ occurs in an ultimate step due to the temperature effect $[12,27]$. The sequence of the $\mathrm{ZnO}$ deposition can be summarized by the following equations:

$$
\begin{aligned}
& \mathrm{NO}_{3}{ }^{-}+\mathrm{H}_{2} \mathrm{O}+2 \mathrm{e}^{-} \rightarrow \mathrm{NO}_{2}{ }^{-}+2 \mathrm{OH}^{-} \\
& \mathrm{Zn}^{2+}+2 \mathrm{OH}^{-} \rightarrow \mathrm{Zn}(\mathrm{OH})_{2} \\
& \mathrm{Zn}(\mathrm{OH})_{2} \rightarrow \mathrm{ZnO}+\mathrm{H}_{2} \mathrm{O}
\end{aligned}
$$


corresponding to the global reaction :

$$
\mathrm{NO}_{3}{ }^{-}+\mathrm{Zn}^{2+}+2 \mathrm{e}^{-} \rightarrow \mathrm{NO}_{2}^{-}+\mathrm{ZnO}
$$

In order to highlight the $\mathrm{ZnO}$ deposition mechanism, voltammetry experiments were performed step by step using a vitreous carbon electrode at $70^{\circ} \mathrm{C}$ : i) in $\mathrm{KCl}$ or $\mathrm{KNO}_{3} \mathrm{Zn}^{2+}$ free blank electrolytes to determine the reduction potentials of $\mathrm{H}^{+}$and $\mathrm{NO}_{3}{ }^{-}$species, ii) in $\mathrm{ZnCl}_{2}+\mathrm{KCl}$ solution to determine the reduction potential of $\mathrm{Zn}^{2+}$ in a nitrate-free medium and iii) in $\mathrm{Zn}\left(\mathrm{NO}_{3}\right)_{2}$ solutions containing both ions at different concentrations. The $\mathrm{pH}$ was always kept at 6.5 by $\mathrm{KOH}$ additions when it was necessary (chloride media) and measured with a $\mathrm{pH}$-meter.

The voltammograms recorded in $\mathrm{KCl}(0.1 \mathrm{M})$ and $\mathrm{KNO}_{3}(0.1 \mathrm{M})$ solutions free of zinc ions are presented in Figure 1. In $\mathrm{KCl}$ containing solution, only the hydrogen evolution reaction can be considered. It corresponds to an equilibrium potential according to the Nernst equation close to $700 \mathrm{mV} / \mathrm{SCE}$. It is then obvious from Figure 1 curve $\mathrm{b}$, that a large overpotential is necessary to reduce $\mathrm{H}^{+}$ions since no significant current is being observed until $-1.2 \mathrm{~V}$ which is in good agreement with the literature [27]. In contrast, in $\mathrm{KNO}_{3}$ containing solution (curve a), the additional nitrate into nitrite reduction is involved with a standard potential of $-0.248 \mathrm{~V} / \mathrm{SCE}$ and an equilibrium potential evaluated neglecting the $\mathrm{NO}_{2}{ }^{-}$concentration to be close to $170 \mathrm{mV} / \mathrm{SCE}$. The current performed on curve 2 reveals that the reduction of nitrate into nitrite ions occurs effectively before that of hydrogen ions, but in a cathodic region around $-1.3 \mathrm{~V} / \mathrm{SCE}$. The large overpotential of $-1.13 \mathrm{~V}$ shows that this reaction is not very favorable from an energy point of view, because the reduction of an anion occurs on the cathode.

Cyclic voltammetry was then performed in solutions containing $5 \mathrm{mM} \mathrm{ZnCl}_{2}$ and $0.1 \mathrm{M} \mathrm{KCl}$ without $\mathrm{NO}_{3}{ }^{-}$ions (Fig. 2). In this case a typical voltamogram for a zinc deposition/dissolution process is obtained according to literature $[31,32]$. No current is observed until $\mathrm{Er}=-1.14 \mathrm{~V}$, which corresponds to the reduction of $\mathrm{Zn}^{2+}$ into metallic $\mathrm{Zn}$. Below that value, there is an increase in cathodic current, due to the zinc crystallization, followed by a current plateau at about $1.5 \mathrm{~mA} / \mathrm{cm}^{2}$ indicating a mass transfer control of the process. The new slight increase in current close to $-1.5 \mathrm{~V}$ corresponds to the $\mathrm{H}^{+}$reduction on zinc with a very slow rate too. By reversing the sweep, a crossover is observed between the backward and the forward currents that is characteristic for a nucleation mechanism. The open circuit potential $-1.07 \mathrm{~V} / \mathrm{SCE}$ is equal to the Nernst potential for a $5 \mathrm{mM} \mathrm{Zn}^{2+}$ concentration. During the reverse anodic scan, an oxidation peak appears which represents the anodic dissolution of the previously deposited zinc metal. 
In order to understand the influence of $\mathrm{NO}_{3}{ }^{-}$during the reduction process, voltammetry was also performed at a constant $\mathrm{Zn}^{2+}$ concentration, by adding $0.01 \mathrm{M} \mathrm{KNO}_{3}$ to the previous solution (Fig. 3b) and from $5 \mathrm{mM} \mathrm{ZnCl}_{2}$ and $0.1 \mathrm{M} \mathrm{KNO}_{3}$ (Fig. 3c). For comparison the curve previously obtained from nitrate free solution is also represented on Figure 3 (curve a). It is obvious that increasing nitrate concentration (from curve a to curve c) leads to:

- A shift of the reduction peak to lower cathodic potential (zone 1) but which remains in the area of $\mathrm{Zn}^{2+}$ reduction. The process remains diffusion-controlled with almost the same shape and the same value of the current peak. Accordingly, this first zone could correspond to $\mathrm{Zn}^{2+}$ reduction into metal with a depolarization effect of nitrate (curve c) in comparison to chloride (curves a and b); the strong adsorption of $\mathrm{Cl}^{-}$and its blocking effect is a phenomenon already clearly established [33].

- A current enhancement (zone 2) around $\mathrm{E}=-1.3 \mathrm{~V}$ that increases with the nitrate concentration and hides partially the limiting current of $\mathrm{Zn}^{2+}$ diffusion. It can be attributed to the nitrate reduction into nitrite in good correlation with the results in Figure 1.

- The progressive disappearance of the anodic peak due to zinc metal dissolution with increasing nitrate ion concentration, which indicates that no zinc metal is obtained.

Figure 4 shows the effect of increasing zinc (II) concentration at constant nitrate concentration $\left(0.2 \mathrm{M} \mathrm{KNO}_{3}\right)$. At high nitrate concentration no anodic peak is observed as seen in Figure 3. The two reduction potential zones previously obtained are still present: in the first one (Zone 1), the cathodic current increases rapidly and reaches a plateau whose current value is clearly linearly dependent on the zinc concentration (see Fig. 5). This zone can be definitively attributed to the $\mathrm{Zn}^{2+}$ reduction into metallic $\mathrm{Zn}$ rather than $\mathrm{NO}_{3}^{-}$reduction which is kept at constant concentration. In the second zone (zone 2), the current increase that arises in addition to the limiting current is almost invariable in accordance with the constant nitrate concentration, but appears earlier when the zinc concentration is higher. Yoshida et al. [28] reported the same effect with increasing concentration of $\mathrm{Zn}^{2+}$ ions in a solution of $\mathrm{Zn}\left(\mathrm{NO}_{3}\right)_{2}$ and $\mathrm{KNO}_{3}$ and claimed a catalytic role of $\mathrm{Zn}^{2+}$ in reducing $\mathrm{NO}_{3}^{-}$ions. Azaceta et al [22] observed a similar behavior in oxygenated ionic liquid but ruled out the reduction of $\mathrm{Zn}^{2+}$ as there is no zinc oxidation peak, attributing this behavior to the catalytic role of $\mathrm{Zn}$ (II) for $\mathrm{O}_{2}$ reduction. However, to explain the disappearance of the anodic peak due to the oxidation of metallic $\mathrm{Zn}$ formed in zone 1 and the subsequent displacement of the equilibrium of the $\mathrm{NO}_{3}{ }^{-}$reduction reaction, we propose two parallel mechanisms in function of the potential applied: 
In zone $1, \mathrm{Zn}^{2+}$ reduction leads to a metallic $\mathrm{Zn}$ deposit that can react chemically (as reductive species) with $\mathrm{NO}_{3}{ }^{-}$ions (as oxidizing species) to become $\mathrm{ZnO}$. The possible reactions for the $\mathrm{ZnO}$ film formation are:

$$
\begin{array}{ll}
\mathrm{Zn}^{2+}+2 \mathrm{e}^{-} \rightarrow \mathrm{Zn} & \left(\mathrm{E}^{\circ}=-1.0 \mathrm{~V} / \mathrm{SCE}\right) \\
\mathrm{NO}_{3}{ }^{-}+\mathrm{H}_{2} \mathrm{O}+2 \mathrm{e}^{-} \rightarrow \mathrm{NO}_{2}{ }^{-}+2 \mathrm{OH}^{-} & \left(\mathrm{E}^{\circ}=-0.248 \mathrm{~V} / \mathrm{SCE}\right) \\
\mathrm{Zn}+\mathrm{NO}_{3}{ }^{-}+\mathrm{H}_{2} \mathrm{O} \rightarrow \mathrm{NO}_{2}{ }^{-}+2 \mathrm{OH}^{-}+\mathrm{Zn}^{2+} & \\
\mathrm{Zn}^{2+}+2 \mathrm{OH}^{-} \rightarrow \mathrm{Zn}(\mathrm{OH})_{2} & \\
\mathrm{Zn}(\mathrm{OH})_{2} \rightarrow \mathrm{ZnO}+\mathrm{H}_{2} \mathrm{O}
\end{array}
$$

leading to the global mechanism between metallic $\mathrm{Zn}$ and nitrate ions:

$$
\mathrm{Zn}+\mathrm{NO}_{3}{ }^{-} \rightarrow \mathrm{NO}_{2}{ }^{-}+\mathrm{ZnO}
$$

with a corresponding free energy of $\Delta \mathrm{G}^{\circ}=-244 \mathrm{KJ} / \mathrm{mol}$ deduced from the thermodynamic data of the species involved in reaction (6).

For more cathodic potentials in zone 2, the nitrate reduction potential is reached: the widely accepted mechanism of $\mathrm{NO}_{3}{ }^{-}$reduction and $\mathrm{ZnO}$ precipitation proposed in reaction (4) could then arise in parallel to that we proposed in reaction (6).

$$
\mathrm{NO}_{3}^{-}+\mathrm{Zn}^{2+}+2 \mathrm{e}^{-} \rightarrow \mathrm{NO}_{2}^{-}+\mathrm{ZnO}
$$

The fact that in the literature the first mechanism was never mentioned could be attributed to the substrate effect that allows the nitrate reduction at a less cathodic potential than the potential observed on vitreous carbon. For example, on ITO [34, 35, 36] $\mathrm{ZnO}$ deposits were obtained between -700 and $-1100 \mathrm{mV}$, where $\mathrm{Zn}^{2+}$ reduction potential into zinc was not yet reached. In this case, the nitrate in nitrite reduction being more favorable on ITO than on vitreous carbon, the only mechanism should be the nitrate reduction that leads to the $\mathrm{ZnO}$ precipitation. On the other hand, on vitreous carbon no $\mathrm{ZnO}$ deposition was obtained until -1.1 V. Below this potential, the parallel mechanism proposed in (6) appeared likely while the reduction of nitrate was kinetically blocked till $-1.3 \mathrm{~V}$.

In order to confirm the direct reaction between metallic $\mathrm{Zn}$ and nitrate, experiments were performed using a bulk zinc electrode. The cyclic voltammograms at $70^{\circ} \mathrm{C}$ on a $\mathrm{Zn}$ metallic electrode in $0.1 \mathrm{M} \mathrm{KNO}_{3}$ were recorded between -0.8 and $-1.6 \mathrm{~V}$ (Fig. 6a) and compared with the 
result obtained on the same electrode in $0.1 \mathrm{M} \mathrm{KCl}$ solution (Fig. 6b). In the cathodic areas, at potentials between -1.1 and $-1.6 \mathrm{~V}$, the $\mathrm{Zn}$ electrode is more active in $\mathrm{KNO}_{3}$ than in $\mathrm{KCl}$ solution showing a similar result than that obtained on vitreous carbon (cf Fig. 1): the nitrate reduction on zinc occurs at $-1.2 \mathrm{~V}$ before the hydrogen evolution reaction $(-1.4 \mathrm{~V})$ that shows a high reduction overpotential. Considering the anodic part, it is obvious that in chloride medium an important oxidation current due to zinc oxidation is observed, that increases with the potential. Inversely, the anodic scan in nitrate solution does not exhibit an active dissolution region, with an anodic current close to zero whatever the potential. The absence of active dissolution is then definitively attributed to the spontaneous passivation of zinc, already assumed from Figures 3 and 4. This result is in good agreement with that obtained by M. A. Amin [29], who studied extensively the passivation of zinc electrodes by $\mathrm{ZnO}$ in nitrate baths.

A new bulk zinc electrode was let at open circuit potential in nitrate oxygen free solution at $70^{\circ} \mathrm{C}$, without any polarization, to confirm the formation of $\mathrm{ZnO}$ by the direct mechanism proposed in reaction 6). The time of experiment was one hour in order to grow a layer sufficiently thick to be analyzed. After the experiment a white color appeared on the surface. Morphological and structural analyses were made by MEB and XRD before and after formation of this deposit (Fig. 7 and 8). The chemically grown deposit (fig 7a) completely covers the substrate and consists of small dense and aggregated slightly elongated crystallites. In contrast, before the experiment the bare Zinc substrate (fig $7 \mathrm{~b}$ ) presents only some stripes which are characteristic of the polishing. The XRD diffractogram made on the bare zinc (fig 8a) is consistent with $\mathrm{Zn}$ hexagonal phase (according to the JCPDS $\mathrm{N}^{\circ} 4-0831$ file).with a preferential 101 orientation. After the experiment (fig 8b), a new $\mathrm{ZnO}$ phase can clearly be identified. Four new peaks at $31.68,34.41,36.27$ and $47.48^{\circ}$ have been observed, which were attributed respectively to (100), (002), (101) and (102) planes of the hexagonal $\mathrm{ZnO}$ structure (referenced to JCPDS N³6-1451 file).

\subsection{Deposit characterization}

\subsubsection{Scanning Electron Microscopy}

Polarization of a vitreous carbon electrode was performed at $-0.7 \mathrm{~V},-1.1 \mathrm{~V}$ (zone 1) and $-1.3 \mathrm{~V}$ (zone 2), during $20 \mathrm{~min}$ in zinc nitrate solution. In accordance with the voltammetric study, no deposit can be obtained for cathodic potentials below -1.1 V. Figure 9 compares the morphology of deposits grown at deposition potentials of -1.1 ( $a$ and $b$ ) and $-1.3 \mathrm{~V}$ (c and d). It can be seen 
that the $\mathrm{ZnO}$ nanorods grown at $-1.1 \mathrm{~V}$ have relatively uniform rod structures and stand perpendicular onto the substrate. The high magnification SEM image (Fig. 9 b) shows the edges and corners of the hexagonal $\mathrm{ZnO}$ nanorods and demonstrates the good crystallinity of the $\mathrm{ZnO}$. When the cathodic potential was increased to $-1.3 \mathrm{~V}$, a strong change in $\mathrm{ZnO}$ morphology was observed (Fig. 9 c and d). One can see two different kinds of crystallization: an oriented compact layer consisting of small crystallites is present on the whole surface that looks like the deposit obtained at $-1.1 \mathrm{~V}$; this first layer is partially covered by a second one consisting of larger irregular aggregates with a random orientation. Getting this double structure could be related to the formation by the two parallel mechanisms discussed previously. We can also conclude that the deposition potential plays a key role for highly oriented $\mathrm{ZnO}$ nanorod growth. The orientation and uniformity of the nanorods grown at low cathodic potential $-1.1 \mathrm{~V}$ is better than that grown at $-1.3 \mathrm{~V}$. The elemental analysis (not shown here) made by EDX proves that nanorods contain only $\mathrm{Zn}$ and $\mathrm{O}$ species.

\subsubsection{X-ray diffraction patterns}

Figure $10 \mathrm{a}$ and $\mathrm{b}$ exhibit the XRD patterns in the range of $30-50^{\circ}(2 \theta)$ of the $\mathrm{ZnO}$ thin films on vitreous carbon substrates obtained respectively at -1.1 and $-1.3 \mathrm{~V}$, during $20 \mathrm{~min}$. The preferred orientation of $\mathrm{ZnO}$ films was varying with the cathodic potential. The XRD patterns of $\mathrm{ZnO}$ nanorods deposited at $-1.1 \mathrm{~V}$ (Fig. 10a) show four peaks that are indexed to (100), (002), (101) and (102) planes of wurtzite structure. The (002) peak is much higher than the other peaks, indicating a (002) preferential orientation and vertically aligned $\mathrm{ZnO}$ nanorods grown in large areas on the vitreous carbon substrates. At $-1.3 \mathrm{~V}$ (Fig. 10b), the as-deposited $\mathrm{ZnO}$ films present random orientations in agreement with the SEM results. The preferred (002) orientation of $\mathrm{ZnO}$ films was weakened with the increase in cathodic potentials from -1.1 to $-1.3 \mathrm{~V}$, in accordance with the results of Izaki et al. [12]. However, it was in contrast to those from other references $[37,38]$, where the authors claimed that the preferential orientation of the electrodeposited $\mathrm{ZnO}$ films changed from (100) to (002) plane with decreasing cathodic potential. Nevertheless, in these papers, the substrates are different (copper or ITO) and the influence of the substrate on the mechanism of electrodeposition has already been clearly established. In our case, on a vitreous carbon substrate, at low potential, the packed $\mathrm{ZnO}$ obtained via mechanism (6) appears highly oriented. On the contrary, at higher cathodic potential, when the two mechanisms (4) and (6) happen in parallel, the $\mathrm{ZnO}$ film exhibited a random orientation. 


\section{Conclusions}

In this work the indirect cathodic deposition of $\mathrm{ZnO}$ nanorods was explained for the first time by two different mechanisms:

- At lower cathodic potential, $\mathrm{Zn}^{2+}$ reduction is leading first to metallic $\mathrm{Zn}$ deposition which is then chemically oxidized by nitrate ions to form the stable passive $\mathrm{ZnO}$ phase.

- At higher cathodic potential, nitrate reduction results in formation of hydroxide ions followed by their reaction with $\mathrm{Zn}^{2+}$ leading to $\mathrm{ZnO}$ precipitation.

The comparison of the $\mathrm{ZnO}$ formation mechanism in function of the substrate (vitreous carbon and ITO glass) should be an important study, intended for future work and further publication. Experimental observations from CV studies reveal that a window between $(-1.1$ and $-1.3 \mathrm{~V})$ is suitable for the formation of $\mathrm{ZnO}$ films on vitreous carbon. Well-oriented $\mathrm{ZnO}$ nanorods can be grown on vitreous carbon at low cathodic potential from $\mathrm{Zn}\left(\mathrm{NO}_{3}\right)_{2}$ solution. A structural analysis elucidates the polycrystalline nature of $\mathrm{ZnO}$ with a preferential orientation along (002) for the samples deposited at $-1.1 \mathrm{~V}$ (SCE). The corresponding SEM pictures show a compact and homogenous structure of nanorods.

\section{Acknowledgments}

The authors wish to acknowledge the A. Tonetto of Aix-Marseille University for SEM observations and C. Chassigneux for XRD analysis.

\section{References:}

[1] Y. Kashiwaba, F. Katahira, K. Haga, T. Sekiguchi, H. Watanabe, J. Cryst. Growth 221 (2000) 431.

[2] V. Sallet, C. Thaindoume, J.F. Rommeluere, A. Kusson, A. Riviere, J.P.Riviere, O. Gorochov, R. Triboulet, V. Munoz-Sanjose, Mater. Lett. 53 (2002) 126. 
[3] Y. Natsume, H. Sakata, Thin Solid Films 372 (2000) 30.

[4] V. Musat, B. Teixeira, E. Fortunato, R.C.C. Monterio, Vilarinho, Surf. Coat. Technol. 180 (2004) 659.

[5] W. Tang, D.C. Cameron, Thin Solid Films 238 (1994) 83.

[6] V. Gupta, A. Mansingh, J. Appl. Phys. 80 (1996) 1063.

[7] X.W. Sun, R.F. Xaio, H.S. Kwok, J. Appl. Phys. 84 (1998) 5776.

[8] P. Nunes, E. Fortunato, R. Martins, Int. J. Inorg. Mater. 3 (2001) 1125.

[9] H. Liu, G. Piret, B. Sieber, J. Laureyns, P. Roussel, W. Xu, R. Boukherroub, S. Szunerits, Electrochem. Com. 11 (2009) 945.

[10] N. Ait Ahmed, G. Fortas, H. Hammache, S. Sam, A. Keffous, A. Manseri, L. Guerbous, N. Gabouze, Appl. Surf. Sci. 256 (2010) 7442.

[11] M. Eyraud, G.Jimenez-Cadena, C. Chassigneux, F. Vacandio, E. Comini, G. Sberveglieri, T. Djenizian, Int. J. Nanotechnol. 9 (2012) 295.

[12] M. Izaki, T. Omi, Appl. Phys. Lett. 68 (1996) 2439.

[13] S. Peulon, D. Lincot, J. Electrochem. Soc. 145 (1998) 864.

[14] A.I. Inamdar, S.H. Mujawar, S.B. Sadale, A.C. Sonavane, M.B. Shelar, P.S. Shinde, P.S. Patil, Solar Energy Materials \& Solar Cells 91 (2007) 864.

[15] S. Peulon, D. Lincot, Adv. Mater. 8 (1996) 166.

[16] J.A. Switzer, Am. Ceram. Bull. 66 (1987) 1521.

[17] Q. Wan, C.L. Lin, X.B. Yu, T.H. Wang, Appl. Phys. Lett. 84 (2004) 124.

[18] T. Mahalingam, V.S. John, M. Raja, Y.K. Su and P.J. Sebastian, Solar Energy Materials \& Solar Cells 88 (2005) 227.

[19] M. Izaki, T. Omi, J. Electrochem. Soc. 144 (1997) L3.

[20] M. Izaki, J. Electrochem. Soc. 146 (1999) 4517.

[21] E. Azaceta, R. Tena-Zaera, R. Marcilla, S. Fantini, J. Echeberria, J.A. Pomposo, H. Grande, D. Mecerreyes, Electrochem Com. 11 (2009) 2184.

[22] E. Azaceta, R. Marcilla, D. Mecerreyes, M. Ungureanu, A.Dev, T.Voss, S. Fantini, H.J. Grande, G. Cabanero and R.Tena-Zaera. Phys. Chem. Chem. Phys. 13(2011)13433.

[23] B.H. Juarez, C. Lopez, C. Alonso, J. Phys. Chem. 108 (2004) 16708.

[24] R. Konenkamp, R.C. World, M. Godinez, Nano Lett. 5 (2005) 2005.

[25] T. Pauporté, D. Lincot, Appl. Phys. Lett. 75 (1999) 3817.

[26] L. Bonou, M. Eyraud, J. Crousier, J. Appl. Electrochem. 24 (1994) 906. 
[27] I. Enculescu, M. Sima, M. Enculescu, M. Enache, V. Vasile and R. Neumann, Optical Materials 30 (2007) 72.

[28] T. Yoshida, D. Komatsu, N. Shimokawa, H. Minoura, Thin Solid Films 45(2004)166.

[29] M.A. Amin, Electrochim. Acta 50 (2005) 1265.

[30] M.R. Khajavi, D.J. Blackwood, G. Cabanero, R. Tena-Zaera, Electrochim. Acta 69 (2012) 181.

[31] A. Hugot-Le Goff, S. Joiret, B. Saïdani, R. Wiart, J. Electroanalytical Chemistry and Interfacial Electrochemistry 263 (1989)127.

[32] C. Cachet, B. Saïdani, R. Wiart, Electrochim. Acta 34 (1989)1249.

[33] M. Wasberg, G. Horányi, Electrochim. Acta 40 (1995) 615.

[34] F. Wang, R. Liu , A. Pan, L. Cao, K. Cheng, B. Xue, G. Wang, Q. Meng, J. Li, Q. Li, Y. Wang, T. Wang, B. Zou, Mater. Let. 61(2007)2000

[35] J.S. Wellings, N.B. Chaure , S.N. Heavens, I.M. Dharmadasa, Thin solid Films 516 (2008) 3893.

[36] Y. Zhang, J. Wenga, Y; Zhanga, L. Xua, J. Xua, X. Huanga, K. Chen, Physica E 27 (2005) 183.

[37] E.A. Dalchiele, P. Giorgi, R.E. Marotti, F. Martin, J.R. Ramos-Barrado, R. Ayouci, D. Leinen, Sol. Ener. Mater. Sol. C 70 (2001) 245.

[38] R.E. Marotti, D.N. Guerra, C. Bello, G. Machado, E.A. Dalchiele, Sol. Ener. Mater. Sol. C $82(2004) 85$. 


\section{Figure captions}

Fig.1: Cyclic voltammograms measured on vitreous carbon in: (a) $0.1 \mathrm{M} \mathrm{KNO}_{3}$, (b) $0.1 \mathrm{M} \mathrm{KCl}, \mathrm{T}=70^{\circ} \mathrm{C}$, scan rate $=20 \mathrm{mV} / \mathrm{s}$.

Fig.2: Cyclic voltammograms measured on vitreous carbon in $0.005 \mathrm{M} \mathrm{ZnCl}_{2}+0.1 \mathrm{M} \mathrm{KCl}, \mathrm{T}=70^{\circ} \mathrm{C}$, scan rate $=20 \mathrm{mV} / \mathrm{s}$.

Fig.3: Cyclic voltammograms measured on vitreous carbon at a constant $\left[\mathrm{Zn}^{2+}\right]=0.005 \mathrm{M}$ : (a) $0.005 \mathrm{M}$ $\mathrm{ZnCl}_{2}+0.1 \mathrm{M} \mathrm{KCl}$, (b) $0.005 \mathrm{M} \mathrm{ZnCl}_{2}+0.01 \mathrm{M} \mathrm{KNO}_{3}+0.1 \mathrm{M} \mathrm{KCl}$, (c) $0.005 \mathrm{M} \mathrm{Zn}\left(\mathrm{NO}_{3}\right)_{2}+0.1 \mathrm{M} \mathrm{KNO}_{3}$, $\mathrm{T}=70^{\circ} \mathrm{C}$, scan rate $=20 \mathrm{mV} / \mathrm{s}$.

Fig.4: Cyclic voltammograms measured on vitreous carbon at $\left[\mathrm{NO}_{3}{ }^{-}\right]=0,2 \mathrm{M}$ : (a) $0.1 \mathrm{M} \mathrm{Zn}\left(\mathrm{NO}_{3}\right)_{2}$, (b) $0.05 \mathrm{M} \mathrm{Zn}\left(\mathrm{NO}_{3}\right)_{2}+0.1 \mathrm{M} \mathrm{KNO}_{3}$, (c) $0.005 \mathrm{M} \mathrm{Zn}\left(\mathrm{NO}_{3}\right)_{2}+0.19 \mathrm{M} \mathrm{KNO}_{3}, \mathrm{~T}=70^{\circ} \mathrm{C}$, scan rate $=20 \mathrm{mV} / \mathrm{s}$.

Fig.5: Effect of $\mathrm{Zn}^{2+}$ concentration on the limiting current density determined from voltammograms shown in Fig.4.

Fig.6: Cyclic voltammograms of a Zinc electrode in: (a) $0.1 \mathrm{M} \mathrm{KNO}_{3}$, (b) $0.1 \mathrm{M} \mathrm{KCl}$, recorded between -0.5 and $-1.6 \mathrm{~V} / \mathrm{SCE}$ at $70^{\circ} \mathrm{C}$ and $20 \mathrm{mV} / \mathrm{s}$.

Fig.7: SEM image of (a) a new bulk Zinc electrode immerged $1 \mathrm{~h}$ in $0.1 \mathrm{M} \mathrm{KNO}_{3}$, (b) the same bulk zinc before immersion.

Fig.8: XRD pattern for (a) a new bulk zinc electrode before experiment, (b) after its immersion during $1 \mathrm{~h}$ in $0.1 \mathrm{M} \mathrm{KNO}$.

Fig.9: SEM images of the $\mathrm{ZnO}$ nanorods electrodeposited on vitreous carbon from $0.005 \mathrm{M}$ $\mathrm{Zn}\left(\mathrm{NO}_{3}\right)_{2}+0.1 \mathrm{M} \mathrm{KNO} 3$ solution at $70^{\circ} \mathrm{C}$ for $20 \mathrm{~min}$ (a) and (b) for $\mathrm{E}=-1.1 \mathrm{~V} / \mathrm{SCE}$; (c) and (d) for $\mathrm{E}=-1.3 \mathrm{~V} / \mathrm{SCE}$.

Fig.10: XRD pattern of films obtained from $0.005 \mathrm{M} \mathrm{Zn}\left(\mathrm{NO}_{3}\right)_{2}+0.1 \mathrm{M} \mathrm{KNO} 3$ for $20 \mathrm{~min}$. (a) at $-1.1 \mathrm{~V} / \mathrm{SCE}$, (b) at $-1.3 \mathrm{~V} / \mathrm{SCE}$ 